\title{
Decline in the Cellular Gontent of RNA, Protein and Dry Weight during the Logarithmic Growth of Euglena gracilis
}

\author{
By D. E. BUETOW AND B. H. LEVEDAHL \\ Gerontology Branch, National Institutes of Health, Baltimore City Hospitals, \\ Baltimore, Maryland, and Department of Zoology, University of California, \\ Los Angeles, California, U.S.A.
}

(Received 3 October 1961)

\begin{abstract}
SUMMARY
Determinations of the cellular content of RNA, total protein and dry weight of Euglena gracilis at different times during logarithmic growth indicated that these parameters did not reflect the constant reproductive rate of these organisms during this period of growth. During exponential growth, the RNA content was reduced by $37 \%$, the total protein by $45 \%$ and the dry weight by about $76 \%$. In addition, the RNA and protein content of Euglena showed a similar pattern of decline as growth progressed; the DNA content, however, remained constant throughout the logarithmic growth phase.
\end{abstract}

\section{INTRODUCTION}

Various growth phases are observed when micro-organisms are grown in culture flasks. One of these growth phases, the logarithmic phase, is characterized by a constant reproductive rate, and it is often assumed that this constancy is reflected in other cellular properties. Consequently, this period of growth has been used when cells in the same physiological state are required for biochemical and biophysical experimentation. The question arises whether or not this assumption of constancy in cellular properties other than the reproductive rate is valid. The problem can be investigated by determining the content/cell of various constituents at different times during logarithmic growth. The constituents to be studied would logically include deoxyribosenucleic acid (DNA), ribosenucleic acid (RNA) and proteins, especially since these are involved in the synthesis of other cellular materials (Brachet, 1957, 1960; Chargraff \& Davidson, 1955). The present paper reports such an analysis of the DNA, RNA, total protein content and dry weight of the flagellate protozoan Euglena gracilis at different times in its logarithmic phase of growth.

\section{METHODS}

Growth. Experimental and stock cultures of a streptomycin-bleached strain, SM-Ll, of Euglena gracilis var. bacillaris were grown in the dark on a defined medium (Cramer \& Myers, 1952) with $\mathrm{Na}$ acetate $(0.061 \mathrm{M})$ as sole carbon source. All growth studies were carried out at $25^{\circ}$ and $\mathrm{pH} 6 \cdot 8$. The generation time of Euglena on this medium was about $22 \mathrm{hr}$. (Buetow \& Levedahl, 1960).

Dry-weight determination. Triplicate samples of 1 to $2 \times 10^{6}$ organisms were dried 
to constant weight at $105^{\circ}$ on previously weighed planchets. The weight of the dried organisms was determined on a Sartorius-Werke microbalance.

Total protein determination. Total protein was first determined by the biuret reagent described by Knights, MacDonald \& Ploompuu (1957). Each sample contained approximately $10^{6}$ organisms. In later studies, total protein was determined in quadruplicate samples by the Folin phenol reagent method of Lowry, Rosebrough, Farr \& Randall (1951). The Lowry method allows the use of fewer organisms (i.e. $10^{5}$ organisms) per sample. The two methods yielded comparable results.

Nucleic acid determination. The method of Schmidt \& Thannhauser (1945) was considerably modified to determine the RNA and DNA content of the Euglena. The modified method was as follows: duplicate samples $2-3 \times 10^{6}$ organisms were concentrated by centrifugation and successively extracted with $1 \mathrm{ml}$. absolute ethanol, twice with $1 \mathrm{ml}$. of a 50-50 mixture absolute ethanol-ether (v/v), and then with $1 \mathrm{ml}$. absolute ethanol. The organisms were concentrated by centrifugation between each extraction and only the resulting pellets saved. Acid-soluble materials were extracted twice in ice for $15 \mathrm{~min}$. with $1 \mathrm{ml}$. cold $0 \cdot 2 \mathrm{~N}-\mathrm{HClO}_{4}$ and the samples were centrifuged for $1 \mathrm{~min}$. at $2^{\circ}-4^{\circ}$. The resulting pellet was incubated with $0.5 \mathrm{ml}$. $\mathrm{N}-\mathrm{NaOH}$ at $30^{\circ}$ for $16 \mathrm{hr}$, neutralized with $0.5 \mathrm{ml}$. $\mathrm{N}-\mathrm{HCl}$ and chilled in ice for $10 \mathrm{~min}$. The samples were next extracted twice with a total of $3 \mathrm{ml}$. cold $\mathrm{N}-\mathrm{HClO}_{4}$ and centrifuged at $2^{\circ}-4^{\circ}$ for $5 \mathrm{~min}$. The resulting supernatant fluids were read at 260 and $315 \mathrm{~m} \mu$ in a Beckman DU spectrophotometer against a $\mathrm{N}-\mathrm{HClO}_{4}$ blank. The difference in readings (i.e. $O D_{260}-O_{315}$ ) gives the RNA fraction.

The pellet was twice incubated with a total of $1 \cdot 3 \mathrm{ml}$. $\mathrm{N}-\mathrm{HClO}_{4}$ at $90^{\circ}$ for $10 \mathrm{~min}$., cooled in ice and centrifuged for $4 \mathrm{~min}$. The resulting supernatant fluids were read in a Beckman spectrophotometer at 267 and $315 \mathrm{~m} \mu$. The difference in readings (i.e. $\mathrm{OD}_{267}-\mathrm{OD}_{315}$ ) gives the DNA fraction (DeDeken-Grenson \& DeDeken, 1959). It was found that a single extraction with $\mathrm{HClO}_{4}$ for the $\mathrm{DNA}$ fraction gave variable results with Euglena, whereas double extractions with $\mathrm{HClO}_{4}$ gave consistent results. The DNA values reported in the present paper agree with those reported by Neff (1960) for colourless Euglena. The amounts of RNA and DNA present in a sample were determined by using the optical density conversion factors derived by DeDeken-Grenson \& DeDeken (1959); these values were converted to $\mu \mathrm{g} . \mathrm{RNA}$ or $\mu \mathrm{g} . \mathrm{DNA} / 10^{6}$ organisms.

\section{RESULTS}

During logarithmic growth, both the dry weight and total protein content of the Euglena decreased as growth progressed (Table 1). There was an early threefold decrease, a levelling-off, and then further decline in the dry-weight measurements. The total protein content per million organisms decreased from about 500 to $285 \mu \mathrm{g}$. in Expt. 1 and from 536 to $295 \mu \mathrm{g}$. over a comparable growth range (Expt. 2). This latter measurement represents a $45 \%$ decrease in the total protein content per average organism during the logarithmic phase of the growth cycle.

The RNA and DNA contents of the Euglena were also determined at various points in their logarithmic growth phase. Results of these experiments are presented in Table 2. Expt. 1 indicated a decrease in the RNA content as growth progressed. Expt. 2 was so planned that measurements were taken at Euglena concentrations 
intermediate between those reported in Expt. 1. In Expt. 2, the RNA content/ million Euglena declined from $34 \cdot 7$ to $21 \cdot 9 \mu \mathrm{g}$., a decrease of $37 \%$ during logarithmic growth. The DNA content of the Euglena remained constant during the exponential growth phase in all experiments. However, at the beginning of the stationary phase of the growth cycle (i.e. 335,000-340,000 Euglenas/ml.), both the RNA and

Table 1. Total protein and dry weight of Euglena during logarithmic growth

\begin{tabular}{|c|c|c|c|}
\hline Expt. & $\begin{array}{c}\text { Concentration } \\
\text { (organisms/ml. } \\
\text { medium) }\end{array}$ & $\begin{array}{c}\text { Total protein* } \\
\left(\mu \mathrm{g} / 10^{6} \text { organisms }\right)\end{array}$ & $\begin{array}{c}\text { Dry weight } \\
\text { (mg./10 } 10^{6} \text { organisms) }\end{array}$ \\
\hline \multirow[t]{5}{*}{1} & $\begin{array}{l}20,200 \dagger \\
36,600\end{array}$ & $498 \pm 34 \cdot 8$ & $\begin{array}{l}3.57 \pm 0.04 \\
1.19 \pm 0.01\end{array}$ \\
\hline & 123,000 & - & $1.06 \pm 0.02$ \\
\hline & 158,000 & $348+26 \cdot 0$ & $0.84 \pm 0.02$ \\
\hline & 170,000 & $329 \pm 29 \cdot 9$ & - \\
\hline & 237,000 & $285 \pm 24 \cdot 1$ & - \\
\hline \multirow[t]{7}{*}{2} & 13,000 & $551 \pm 9.5$ & - \\
\hline & 23,400 & $536 \pm 26.9$ & - \\
\hline & 38,100 & $375 \pm 17 \cdot 6$ & - \\
\hline & 64,500 & $378 \pm 11 \cdot 5$ & - \\
\hline & 120,000 & $386 \pm 13 \cdot 3$ & - \\
\hline & 259,000 & $295 \pm 11 \cdot 2$ & - \\
\hline & $335,000 \ddagger$ & $302 \pm 21 \cdot 0$ & - \\
\hline
\end{tabular}

* Measured by the method of Knights et al. (1957) in Expt. 1 and by the method of Lowry et al. (1951) in Expt. 2. Values given are the mean \pm standard deviation.

$\dagger$ End of the lag phase, beginning of the logarithmic growth phase.

$\ddagger$ Beginning of stationary phase of growth cycle.

Table 2. $R N A$ and $D N A$ content of Euglena during logarithmic growth

\begin{tabular}{|c|c|c|c|}
\hline Expt. & $\begin{array}{l}\text { Concentration; } \\
\text { organisms/ml. } \\
\text { medium }\end{array}$ & $\begin{array}{c}\text { RNA* } \\
\left(\mu \mathrm{g} \cdot / 10^{6}\right. \\
\text { organisms })\end{array}$ & $\begin{array}{c}\text { DNA* } \\
\left(\mu \mathrm{g} \cdot / 10^{6}\right. \\
\text { organisms })\end{array}$ \\
\hline 1 & $\begin{array}{c}42,800 \\
87,700 \\
175,000 \\
290,000 \\
340,000 \dagger\end{array}$ & $\begin{array}{l}30 \cdot 2 \\
30 \cdot 2 \\
27 \cdot 8 \\
26 \cdot 9 \\
32 \cdot 3\end{array}$ & $\begin{array}{l}4 \cdot 34 \\
4 \cdot 34 \\
4 \cdot 08 \\
4 \cdot 14 \\
4 \cdot 72\end{array}$ \\
\hline 2 & $\begin{array}{c}23,4,00 \\
38,100 \\
64,500 \\
120,000 \\
259,000 \\
335,000 \dagger\end{array}$ & $\begin{array}{l}34 \cdot 7 \\
30 \cdot 2 \\
29 \cdot 2 \\
27 \cdot 7 \\
21 \cdot 9 \\
31 \cdot 0\end{array}$ & $\begin{array}{l}4 \cdot 17 \\
4 \cdot 63 \\
4 \cdot 60 \\
4 \cdot 39 \\
5 \cdot 12\end{array}$ \\
\hline
\end{tabular}

* Mean of duplicate samples; in these experiments, the average deviation between duplicate samples was $1 \cdot 1 \mu \mathrm{g} . / 10^{6}$ organisms for RNA and $0 \cdot 4 \mu \mathrm{g} . / 10^{6}$ organisms for DNA.

$\dagger$ Beginning of the stationary phase of the growth cycle.

the DNA content increased (Table 2). Such a finding probably results from the fact that a culture in the stationary phase of the growth cycle is essentially a nondividing one. Under such conditions, the cell constituents would be expected to 'pile up', at least initially. Of further interest is the similar decrease of RNA and total protein of Euglena during exponential growth. Figure 1 presents the 
results of an experiment in which both RNA and protein were measured in the same culture during its exponential growth phase. Although the protein initially decreased faster than the RNA, its overall pattern of decline was similar to that of the RNA. After an initial sharp decrease, there is a levelling-off of in the decline of RNA and protein during the middle of logarithmic growth, followed by another sharp decline late in the exponential growth period. This observation appears to be in line with the often demonstrated influence of RNA and protein syntheses on each other (Brachet, 1957).

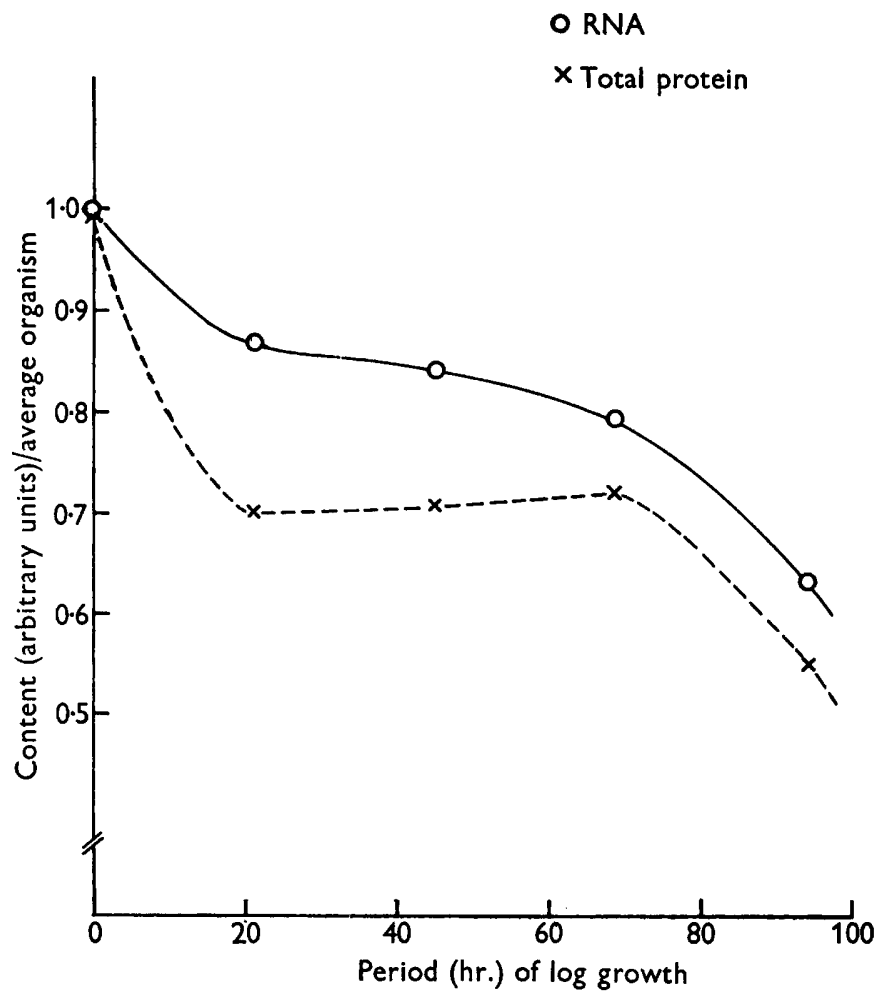

Fig. 1. Decline in mean RNA and total protein content per average Euglena cell during logarithmic growth. Zero time represents the beginning of logarithmic growth. The generation time of Euglena is about $22 \mathrm{hr}$. In order to show the similarity in decline, both the RNA and total protein content per average cell are given in arbitrary units. (See Tables 1 and 2 for actual values.)

\section{DISCUSSION}

The constant reproductive rate of Euglena gracilis during logarithmic growth is not reflected in the RNA or total protein contents or dry weight of these organisms. The authors believe the present observations are the first to demonstrate a variability in such cellular parameters during the logarithmic growth of protozoa. These results are reminiscent of those obtained with bacteria and mammalian cell lines maintained in culture. The HeLa cell (Salzman, 1959) as well as other mammalian cells of carcinogenic origin (Swaffield \& Foley, 1960) show systematic fluctuations in cellular protein, RNA and DNA content and protein composition (Kruse, Schooler \& 
White, 1960) during logarithmic growth. Morse \& Carter (1949) showed a rapid decline in the RNA content of Escherichia coli during the early part of its logarithmic growth phase. The data of Dean \& Hinshelwood (1959) on Aerobacter aerogenes and of Belozersky (1960) on Azotobacter agile indicate a continuous decline in the RNA content of these organisms during exponential growth. The cell size of $A$. aerogenes also decreased during this period of growth (Dean \& Hinshelwood, 1959). The decrease in dry weight as well as in the cellular content of RNA and protein during the exponential growth of Euglena gracilis examined here suggests that these substituents are synthesized and accumulated during the lag phase of growth. Such a synthesis and accumulation of nucleic acid and protein during the lag phase was shown for bacteria such as $A$. agile (Belozersky, 1960), A. aerogenes (Dean \& Hinshelwood, 1959; Neidhardt \& Magasanik, 1960) and $E$. coli (Morse \& Carter, 1949) and various mammalian cells (Salzman, 1959; Swaffield \& Foley, 1959). These observations indicate that the lag phase is a period of intense metabolic activity related primarily to protoplasmic growth rather than cell division. The decline in RNA, protein and, especially, dry weight during the exponential growth of Euglena gracilis suggests that other cell parameters, i.e. lipids, carbohydrates, etc., may also change during this period of growth. Therefore, before any such parameter is used as an indication of the amount of cell population, its measurement should be completed throughout the growth cycle.

The authors wish to thank Dr J. J. Blum of the Gerontology Branch, National Heart Institute, for aid with the RNA-DNA method, and Mrs M. Robinson for technical assistance. Some of these data are taken from a dissertation presented (by D.E.B.) in partial fulfilment of the requirements for the degree of Doctor of Philosophy, University of California, Los Angeles, 1959. This work was aided by a contract between the office of Naval Research, Department of the Navy, and the University of Califormia, Los Angeles, NR 120-336.

\section{REFERENCES}

Belozersky, A. N. (1960). In Nucleoproteins, p. 199, ed. by R. Stoops. New York: Interscience Publishers.

Brachet, J. (1957). Biochemical Cytology. New York: Academic Press Inc.

Bracher, J. (1960). Ribonucleic acids and the synthesis of cellular proteins. Nature, Lond. 186, 194.

Buetow, D. E. \& Levedahr, B. H. (1960). Relationships between steroid molecular structure and cell growth. Arch. Biochem. Biophys. 86, 34.

Chargraff, E. \& Davidson, J. N. (1955). The Nucleic Acids, Vol. 2. New York: Academic Press Inc.

Cramer, M. \& Myers, J. (1952). Growth and photosynthetic characteristics of Euglena gracilis. Arch. Mikrobiol. 17, 384.

Dean, A. C. R. \& Hinshelwood, Sir C. (1959). In Regulation of Cell Metabolism, p. 311, ed. by G. E. W. Wolstenholme \& C. M. O'Connor. Boston: Little, Brown and Co.

DeDeken-Grenson, M. \& DeDeken, R. H. (1959). Elimination of substances interfering with nucleic acid determination. Biochim. biophys. Acta, 31, 195.

Knights, E. M., MacDonald, R. P. \& Ploompuu, J. (1957). Ultramicro Methods for Clinical Laboratories, p. 83. New York: Grune and Stratton.

Kruse, P. F., Jun., Schooler, E. J. \& White, P. B. (1960). Changes in protein-bound acid-amide ratios during culture of Walker Carcinosarcoma 256 cells in vitro. Biochim. biophys. Acta, 41, 375. 
Lowry, D. H., Rosebrough, N. J., Farr, A. L. \& Randall, R. J. (1951). Protein measurement with the Folin phenol reagent. J. biol. Chem. 193, 265.

Morse, M. L. \& CarTer, C. E. (1949). The synthesis of nucleic acids in cultures of Escherichia coli, strains $B$ and B/r. J. Bact. 58, 321.

NEFF, R. H. (1960). Volume, nucleic acid and nitrogen contents of strains of green and colourless Euglena gracilis and of Astasia longa. J. Protozool. 7, 69.

Neidhardt, F. C. \& Magasanik, B. (1960). Studies on the role of ribonucleic acid in the growth of bacteria. Biochim. biophys Acta, 42, 99.

Salzman, N. P. (1959). Systematic fluctuations in the cellular protein, RNA and DNA during growth of mammalian cell cultures. Biochim. biophys. Acta, 31, 158.

Schmidt, G. \& Thannhauser, S. J. (1945). A method for the determination of DNA, RNA and phosphoproteins in animal tissues. J. biol. Chem. 161, 83.

Swaffield, M. N. \& Foley, G. E. (1960). Changes in the cellular content of RNA, DNA and protein in cultured cells during logarithmic growth. Arch. Biochem. Biophys. 86, 219. 